\title{
CONCENTRATION OF HEAVY METALS IN THE TISSUES OF SPINY MOUSE AS BIO-INDICATORS OF POLLUTION UNDER DIFFERENT ENVIRONMENTAL CONDITIONS IN EGYPT
}

\author{
Eman M.E. Mohallal ${ }^{1^{*}}$ and Mahmoud I. Younes ${ }^{2}$ \\ ${ }^{1}$ Department of Animal and Poultry Physiology, Desert Research \\ Center, El Matareya, Cairo, Egypt \\ ${ }^{2}$ Department of Zoology, Faculty of Science, Al-Azhar University, \\ Nasr City, Cairo, Egypt \\ *E-mail: emanmohallal@yahoo.com
}

he present study was performed to evaluate the
concentration of some heavy metals in liver, kidney and
muscles of the spiny mouse Acomys cahirinus from natural (Dakhla Oasis) and contaminated (Helwan) areas in Egypt. The copper, manganese and nickel concentrations showed highly significant differences in mice's livers between the two study areas. However, there was no difference between sites in measures of heavy metals in the kidney, except copper, which showed highly significant differences. Iron, manganese and zinc concentrations in muscles were significantly different between sites. The pollution factors showed that the kidney is much affected with copper, iron and zinc pollutants higher than in liver and muscles, while nickel and lead concentrations were lower in kidney than in other organs. In general, the tissues of spiny mouse from Dakhla Oasis were affected by heavy metal pollutants, especially copper, iron and manganese, which may affect wildlife and consequently humans' health.

Keywords: spiny mouse, heavy metals, Dakhla Oasis, Helwan, pollution

Living organisms require varying amounts of essential heavy metals, but excessive levels can be harmful to the organism. Other heavy metals, such as $\mathrm{Hg}, \mathrm{Cd}$ and $\mathrm{Pb}$ are toxic and their accumulation over time in the body of organisms may cause serious illness. When organisms are exposed to metals, they can affect all stages of development (Serbaji et al., 2012 and Ogundiran et al., 2012).

Toxic metals are natural components of the environment, but human activities, notably industrial and mining processes, have been responsible for the wider diffusion of these elements. Toxic metals are accumulated in soils 
and plants, and animals fed with these plants will tend to accumulate toxic metals themselves. Although contamination of animal feed by toxic metals cannot be entirely avoided, given the prevalence of these pollutants in the environment. There is a clear need for minimizing such contamination, with the aim of reducing both direct and indirect effects on both animal and human health (SCAN, 2003).

Egypt, as any country in the world, is threated by pollution associated with human activity, especially industrial activity. Helwan area (east of the Nile Valley and south of Cairo) is considered to be an industrialized area with intensive pollution (Abdalla and Scheytt, 2012 and Mohamed et al., 2011). Helwan and its nearby surroundings is considered to be one of the most important industrial districts in Egypt, with all the expected negative side-effects, especially on the environment. This is due to the presence of some large national industrial facilities such as iron, steel, cement, car manufacturing, coal industry and red brick factories. Industries consume significant amounts of water that may return in many cases highly polluted wastewater, sometimes directly to the environment. Hence, these activities are considered as an important source of water pollution (Fayez and Shahin, 2007; Han et al., 2009 and Mahmoodabady et al., 2010).

Dakhla Oasis is a typical dryland, where water and fertile soil are very limited and nonrenewable and there are plans for it to be a reclamation area. The amount, rate and intensity of loss of agricultural land need to be analyzed. Hence, changes in water resource distribution and land cover, along with the environmental impact of these changes, should be carefully considered (Kato and Iwasaki, 2008 and Kato et al., 2010 and 2014).

Due to their wide distribution, small mammals are suitable for studying the effects of pollution in both polluted and unpolluted regions. Rodents can accumulate larger amounts of heavy metals in their tissues, but this does not mean that those species are under the greatest risk of toxic effects from pollution. Rodents play an important role in food webs by acting at different trophic levels. They are prey to a whole range of predatory birds and mammals (Jongbloed et al., 1996). These species are numerous in certain areas and considered as species at risk of toxicological effects of in contaminated ecosystems. It is assumed that metal concentrations in small mammals reflect not only trophic level, but also exposure time and metal concentrations in the exposure areas (Torres and Johnson, 2001).

Industrial and agricultural activities have caused large-scale soil contamination in desert areas. Rodents are sensitive and accurate monitors of exposure to environmental pollution by heavy metals. Moreover, the pattern of heavy metals distribution and their levels in their tissues are similar to those found in humans (Damek-Poprawa and Sawicka-Kapusta, 2003). Studies of contaminant levels in floodplain species have been scarce. Assessments of the risk of contaminant accumulation in floodplain mammals

Egyptian J. Desert Res., 65, No. 1, 61-73 (2015) 
have generally been based on soil contaminant levels combined with accumulation factors, consumption rates and life expectancies (Jongbloed et al., 1996 and Kooistra et al., 2001 and 2005). This study aimed to evaluate the concentration of heavy metals as bio-indicators in the liver, kidney and muscles of the spiny mouse A. cahirinus living in two study areas in Egypt; natural habitat (Dakhla Oasis) and industrial province (Helwan city).

\section{MATERIALS AND METHODS}

\section{Study area}

The study was carried out at two different habitats of spiny mouse, the first was Dakhla Oasis (natural habitat) and the second was Helwan (contaminated habitat). Dakhla Oasis is a closed basin located in the western Desert, Egypt. It lies at $1100 \mathrm{~km}$ south of the Mediterranean shoreline and at $265 \mathrm{~km}$ east of the Libyan border. It lies between longitudes $\left(28^{\circ} 00^{\prime}\right.$ and $\left.29^{\circ} 30^{\prime} \mathrm{E}\right)$ and latitudes $\left(25^{\circ} 25^{\prime}\right.$ and $\left.26^{\circ} 00^{\prime} \mathrm{N}\right)$ with a total area of about $4000 \mathrm{~km}^{2}$. The climate in this part of the eastern Sahara is hyper-arid with an average annual rainfall not exceeding $6 \mathrm{~mm} /$ year. It is characterized by desert climate. The average temperature ranges between $6{ }^{\circ} \mathrm{C}$ in January and $38^{\circ} \mathrm{C}$ in July (EMA, 1996). It contains highly fertile lands is rich in water, and supports a higher population. Dakhla depression extends $155 \mathrm{~km}$ in the east-west direction. The area of the oasis is suitable for agriculture.

On the other hand, Helwan is a part of Greater Cairo, east of the River Nile directly about $20 \mathrm{~km}$ south of Cairo and $40 \mathrm{~m}$ above sea level. It extends between longitude $\left(31^{\circ} 15^{\prime} 31^{\circ} 23^{\prime} \mathrm{E}\right)$ and latitude $\left(29^{\circ} 43^{\prime} 29^{\circ} 51^{\prime}\right.$ $\mathrm{N})$. The area is characterized by an arid climate with warm winter and hot summer with average daily temperature ranging from 14 to $31^{\circ} \mathrm{C}$. The long term average rainfall is about $25.7 \mathrm{~mm} /$ year, evapotranspiration rate ranges from about $256 \mathrm{~mm} /$ year in winter to about $5746 \mathrm{~mm} / \mathrm{year}$ in summer and relative humidity from 50 to $70 \%$ (Elminir et al., 2005).

\section{Animals}

Cairo spiny mouse Acomys cahirinus is native to North Africa with its range extending from Mauritania, Morocco and Algeria in the west to Sudan, Ethiopia, Eritrea and Egypt in the east, at altitudes up to about $1,500 \mathrm{~m}(4,900 \mathrm{ft})$. It lives in dry stony habitats with sparse vegetation and is often found near human dwellings. It is common around cliffs and canyons and in gravelly plains with shrubby vegetation. It is not usually found in sandy habitats, but may be present among date palms. It usually lives in burrows or rock crevices and is mostly terrestrial, but it can also clamber about in low bushes. It is nocturnal and omnivorous. Their diet includes seeds, nuts, fruit, green leaves, insects, spiders and molluscs. When they live in the vicinity of humans, they consume crops, grain, and stored food. They 
sometimes enter houses, especially in winter, and dislike cold weather (Osborn and Helmy, 1980 and Regula, 2012).

Rodents were caught in spring-type traps at the two different localities in Egypt throughout winter 2014. The first locality, Dakhla Oasis at the Western Desert of Egypt is considered a natural area without intensive pollution and with relatively low traffic density, and is referred to as the natural site. The second locality, found around the town of Helwan, is a contaminated area. Forty Sherman traps were set at the evening, collected at the next morning and were baited by bread provided with peanut butter for three nights for each site. Only adult makes, in good physical condition, were brought to the laboratory (seven males from Dakhla Oasis and five from Helwan).

\section{Heavy Metal Analyses}

Samples of $0.25 \mathrm{~g}$ were taken from the liver, kidney and muscles tissues of each mouse, then digested by $7 \mathrm{ml}$ of $65 \% \mathrm{HNO}_{3}$ and $1 \mathrm{ml}$ of $30 \%$ $\mathrm{H}_{2} \mathrm{O}_{2}$ using Microwave Digestion Labstation Closed System (Ethos Pro, Milestone, Italy). The solution was diluted to $25 \mathrm{ml}$ and the concentration of $\mathrm{Cu}, \mathrm{Fe}, \mathrm{Mn}, \mathrm{Ni}, \mathrm{Pb}$ and $\mathrm{Zn}$ was analysed by Inductively Coupled Argon Plasma (ICAP 6500 Duo; Thermo Scientific, England). An amount of 1000 $\mathrm{mg} / \mathrm{l}$ multi-element certified standard solution (Merck, Germany) was used as a stock solution for instrument standardization.

The statistical analysis of the data obtained was done by SPSS version 20 .

\section{RESULTS AND DISCUSSION}

The concentrations of copper, iron, manganese, nickel, lead and zinc in male organs of Acomys cahirinus from two (natural; Dakhla Oasis and industrial; Helwan) sites are listed in table (1). Copper, manganese and nickel showed highly significant differences (Student's t-test: $F=1.85,0.72$ and 22.58, respectively; $\mathrm{df}=5,6$ and 6 , respectively; $\mathrm{P}<0.01$ ) in livers of animals from these two sites. Iron and lead were also significantly different $(\mathrm{P}<0.05)$ in livers of animals from these two sites. Concentrations of heavy metals in kidney showed no significant differences $(\mathrm{P}>0.05)$ between the two studied areas, except copper, which showed a highly significant difference $(\mathrm{F}$ $=113.16 ; \mathrm{df}=4 ; \mathrm{P}<0.01)$. Iron, manganese and zinc in muscles were significantly different between the two studied areas $(\mathrm{F}=3.89,9.06$ and 1.76 respectively; $\mathrm{df}=8 ; \mathrm{P}<0.05)$, while there was no significantly difference $(\mathrm{P}>0.05)$ between nickel and lead in the two studied areas. The pollution factors; the ratio of the concentrations in polluted: unpolluted sites, showed that the kidney is much affected by copper, iron and zinc pollution higher than in liver and muscles, while nickel and lead were much higher in kidney than other organs as shown in table (1).

Egyptian J. Desert Res., 65, No. 1, 61-73 (2015) 


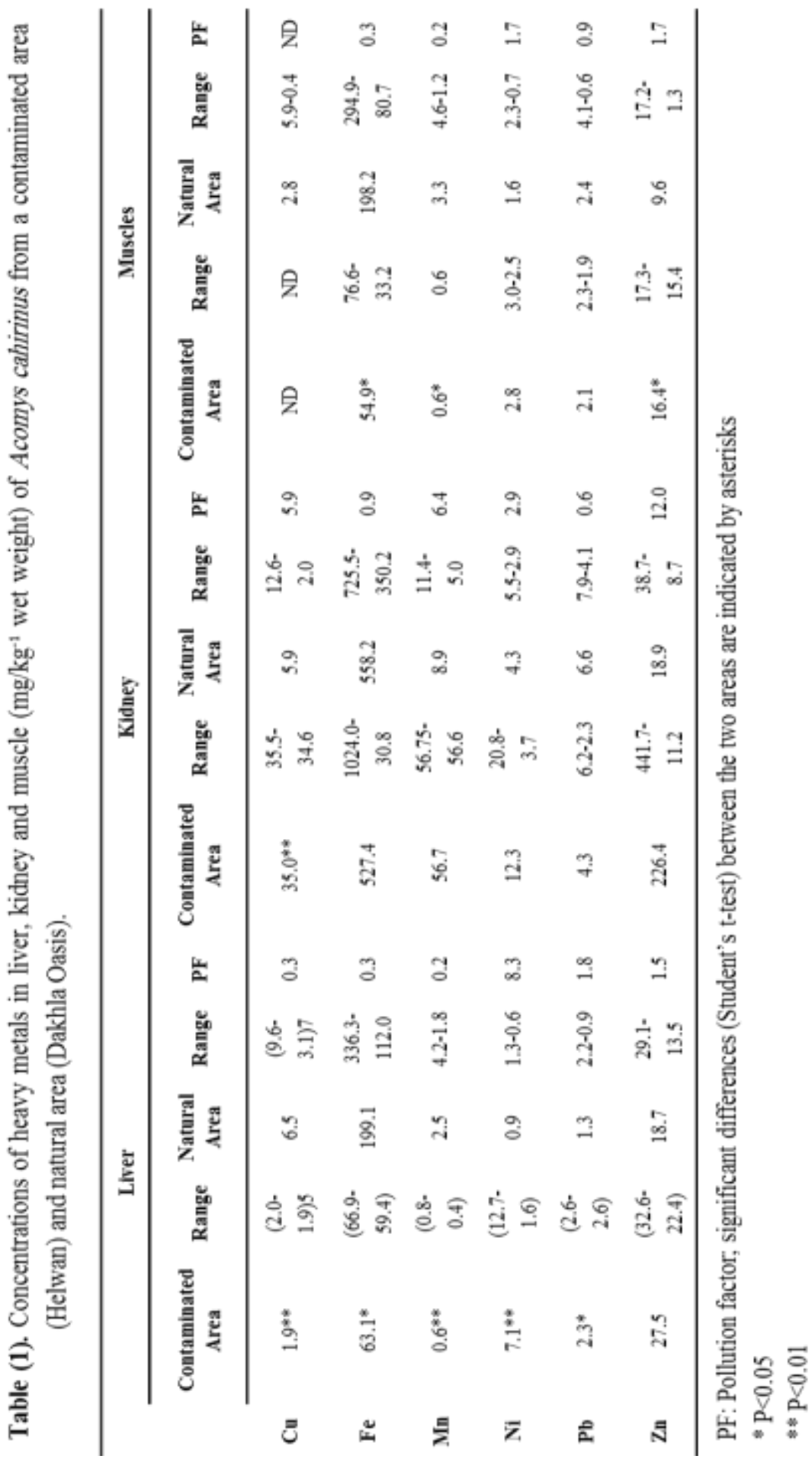

Egyptian J. Desert Res., 65, No. 1, 61-73 (2015) 
Environmental pollution by heavy metals is ubiquitous. This is due to both the natural abundance of metals within earth's crust and human activities (Langner et al., 2011 and Markert et al., 2011). Human activities have many serious impacts on the environment and some of these impacts endure for a long time (Pereira et al., 2006). Some studies have shown high concentrations of heavy metals in mammals that live in polluted areas (Swiergosz-Kowalewska et al., 2005 and Sanchez-Chardi et al., 2007).

Sewage wastewater and sludge, particularly when mixed with industrial waste, contain a large amount of potentially toxic metals, such as $\mathrm{Hg}, \mathrm{Cr}, \mathrm{Pb}, \mathrm{Cd}, \mathrm{Ni}, \mathrm{Co}, \mathrm{Cu}, \mathrm{Zn}, \mathrm{Fe}$ and $\mathrm{Mn}$. Heavy metals exist in different forms (water soluble, exchangeable, organically complex, adsorbed in organic sites, occluded or held in primary minerals). These forms differ in their mobility in soils and extractability by plants. Several metal uptake studies have shown that the water soluble fraction of metals, such as cadmium, lead, mercury and chromium, can be accumulated by living plants and thus enter the animal and human food chain. Some of these heavy metals are essential plant nutrients $(\mathrm{Fe}, \mathrm{Cu}, \mathrm{Mn}, \mathrm{Zn})$, while others $(\mathrm{Cd}, \mathrm{Pb}, \mathrm{Cr}, \mathrm{Hg}$ ) are not. The latter group of heavy metals has not known physiologically beneficial function and are considered toxic to plants (El-Motaium, 2000).

Bioaccumulation of heavy metals in living organisms can be affected by age and sex, but their effects vary greatly between populations and species. Non-essential metals are undesirable in an organism and have toxic effects, while essential ones may have negative effects when they are deficient or in excess (Klaassen, 2001). The uptake and elimination kinetics of heavy metals are not constant during life, but alter during the growth of an animal (Blagojevic et al., 2012). The concentration of heavy metals in animal tissues depends on several factors like the age, physiological state and homeostatic mechanisms of the individual (Sawicka-Kapusta et al., 1995). Nevertheless, the concentration of the different heavy metals in small mammals followa a regular sequence; $\mathrm{Fe}>\mathrm{Zn}>\mathrm{Cu}>\mathrm{Pb}$, with small differences according to the species' lifestyle (Sanchez-Chardi and Nadal, 2007 and Sanchez-Chardi et al. 2007). The results of this study showed that bioaccumulation of the analyzed heavy metals in the spiny mice, from the two studied areas, followed the same sequence. Lead is a toxic element but $\mathrm{Zn}, \mathrm{Fe}$ and $\mathrm{Cu}$ are essential for the normal development and function of the organism (Topolska et al., 2004).

Moreover, $\mathrm{Zn}$ and $\mathrm{Cu}$ also participate in detoxification processes, as part of the enzymes of the antioxidant systems that impede the formation of reactive oxygen species (Sanchez-Chardi and Nadal, 2007). Likewise, iron concentrations reduce the toxic effects of pollutants like cadmium. Beside the importance of these elements for the correct functioning of living mammals, high concentrations or deficiencies of heavy metals could be dangerous to organisms.

Egyptian J. Desert Res., 65, No. 1, 61-73 (2015) 
Heavy metals pollution is a serious environmental issue for not only advanced nations, but also developing nations, because pollution has gradually increasing and removing pollutants from the environment is difficult (Ieradi et al., 1996 and Swarup and Patra, 2005). High concentrations of heavy metals have been found in wild mammals inhabiting polluted areas (Swiergosz-Kowalewska et al., 2005; Sanchez-Chardi and Nadal, 2007 and Sanchez-Chardi et al., 2007).

The critical liver concentrations of $\mathrm{Pb}$ are considered to be around 25-35 $\mu \mathrm{g} . \mathrm{g}^{-1}$ dry weight (Scheuhammer, 1991 and Shore and Douben, 1994). In our study, no individuals of the spiny mouse from the two localities reached this level. Soltan (1999) indicated that the ground water of Dakhla Oasis is free from any obvious pollution, with the exception of $\mathrm{Pb}$, which may cause some problems if used for human consumption (according to national and international standards). The relatively high concentration of lead is due to the rock-water interaction. However, although Ni (0.01-0.07), $\mathrm{Pb}(0.06-0.17), \mathrm{Cr}(0.03-0.14)$ and $\mathrm{Co}(0.06-0.16)$ concentrations (mg l$\left.{ }^{-1}\right)$ were relatively high, they were less than their values in the soil leachate samples from Dakhla Oasis. This suggests that the source of these elements is lithogenic (Soltan, 1999). Relatively high concentrations of these metals are due to the mobility of trace metals in the presence of high concentrations of chloride ions. Chloride complexation increases metal mobility (Doner, 1978) and decreases adsorption.

Iron $\left(0.04-0.3 \mathrm{mg} \mathrm{l}^{-1}\right)$, and manganese $\left(0.17-0.45 \mathrm{mg} \mathrm{l}^{-1}\right)$ concentrations of the examined ground water samples at Dakhala Oasis were within the Egyptian government permitted limits for ground water, due to the mineralogical origin of these elements and the absence of pollution (Soltan and Issa, 1996).

The critical toxic point regarding $\mathrm{Zn}$ concentrations in the kidney and liver of mammals were reported to be 465 and $274 \mu \mathrm{g} / \mathrm{g}$ dry weight, respectively (Swiergosz-Kowalewska et al., 2005). The Zn concentrations in tissues of spiny mouse recorded in the current study were below these points. Markov (2012) obtained Ni concentration in the liver of the fat dormouse (Glis glis) of $0.643 \mathrm{mg} / \mathrm{kg}$ dry weight in an agricultural region of Bulgaria. In the present study, the findings for $\mathrm{Ni}$ concentration in tissues of spiny mouse in an agricultural Dakhla Oasis area were higher than Markov study and confirm the findings of Okati and Rezaee (2013). Bukovjan et al. (1997) reported that the mean copper concentration in the liver of Lepus europaeus was $4.68 \mathrm{mg} \cdot \mathrm{kg}^{-1}$, while in this study the $\mathrm{Cu}$ concentration in liver of spiny mouse was 15.83 and $1.93 \mathrm{mg} . \mathrm{kg}^{-1}$ from Dakhla and Helwan, respectively.

Finding of the present study showed that the risk of damage to liver and kidney of wild spiny mice exists even at relatively low concentrations of cobalt, copper, nickel, lead and zinc concentrations in industrial area. Since rodents serve as sentinels for humans in toxicological investigations of potential risk of exposure (Shore and Rattner, 2001), it is conceivable that

Egyptian J. Desert Res., 65, No. 1, 61-73 (2015) 
heavy metal levels could cause similar histopathological changes in tissues of people living in the examined areas.

In this study, the concentration sequence of heavy metals in liver, kidney and muscles of the spiny mouse was $\mathrm{Fe}>\mathrm{Zn}>\mathrm{Cu}>\mathrm{Mn}>\mathrm{Pb}>\mathrm{Ni}>$ Co that is in agreement with the findings reported by Sumbera et al. (2003), Damek-Poprawa and Sawicka-Kapusta (2004) and Sanchez-Chardi et al. (2007), who stated the same sequence.

Schleich et al. (2010) measured the concentration of heavy metals like $\mathrm{Pb}, \mathrm{Zn}, \mathrm{Fe}$, and $\mathrm{Cu}$ in liver and muscles of a rodent (Ctenomys talarum) in areas with different amount of exposure to pollution. They found that the heavy metal concentration sequence pattern was $\mathrm{Fe}>\mathrm{Zn}>\mathrm{Pb} \approx \mathrm{Cu}$. Pollution factor (PF) values have been widely used in monitoring studies (Fernandez et al., 2000 and Sedki et al., 2003), since they allow estimation of the portion of tissue metal content that has anthropogenic origin.

The present study confirms the presence of heavy metals concentration in different tissues of spiny mouse. The two studied environments of this mouse are exposed to heavy metals. The mouse kidney and liver tissues can accumulate heavy metals pollution than muscle tissue.

\section{CONCLUSION}

The study showed that the spiny mice can accumulate large amounts of heavy metals in their tissues without being under the greatest risk of toxic effects from pollution. This rodent could serve as a model for investigation of potential risk of exposure in humans. It is conceivable that heavy metal levels of copper, iron and manganese can affect people living in Dakhla Oasis, even though this area is not considered to be polluted; clearly heavy metal concentrations in these area need further study.

Ethical approval: "All applicable international, national and/or institutional guidelines for the care and use of animals were followed."

\section{REFERENCES}

Abdalla, F.A. and T. Scheytt (2012). Hydrochemistry of surface water and groundwater from a fractured carbonate aquifer in the Helwan area, Egypt. J. Earth Sys. Sci., 121 (1): 109-124.

Blagojevic, J., V. Jovanovic, G. Stamenkovic, V. Jojic, V. BugarskiStanojevic, T. Adnadevic and M. Vujosevic (2012). Age differences in bioaccumulation of heavy metals in populations of the blackstriped field mouse, Apodemus agrarius (Rodentia; Mammalia). Int. J. Environ. Res., 6 (4): 1045-1052.

Egyptian J. Desert Res., 65, No. 1, 61-73 (2015) 
Bukovjan, K., Z. Wittingerova and E. Cerna (1997). Chemical elements in tissues and histological changes in tissue of hares (Lepus europaeus Pall.). Scientia Agric. Bohemica, 28: 215-226.

Damek-Poprawa, M. and K. Sawicka-Kapuata (2003). Damage to the liver, kidney and testis with reference to burden of heavy metals in yellownecked mice from areas around steelworks and zinc smelters in Poland. Toxicology, 186: 1-10.

Damek-Poprawa, M. and K. Sawicka-Kapusta (2004). Histopathological changes in the liver, kidneys, and testes of bank voles environmentally exposed to heavy metal emissions from the steelworks and zinc smelter in Poland. Environ. Res., 92: 72-78.

Doner, H.E. (1978). Chloride as a factor in mobilities of $\mathrm{Ni}(\mathrm{II}), \mathrm{Co}(\mathrm{II})$ and Cd(II) in soil. Soil Sci. Soc. Am. J., 42: 882.

Elminir, H.K., F.F. Areed and T.S. El Sayed (2005). Estimation of solar radiation components incident on Helwan site using neural networks. Solar Energy, 79: 270-279.

El-Motaium, R.A. (2000). Alleviation of environmental pollution using nuclear techniques recycling of sewage water and sludge in agriculture: a case study ICEHM, Cairo University, Egypt, 323-332.

EMA (Egyptian Meteorological Authority) (1996). In "Climatic Atlas of Egypt". Cairo.

Fayez, M. and R.R. Shahin (2007). Effects of industrial liquid wastes on dinitrogen fixation and microflora of soils and waters; J. Plant Nutr. Soil Sci., 150 (4): 220-227.

Fernandez, J.A., A. Rey and A. Carballeira (2000). An extended study of heavy metal deposition in Galicia (NW Spain) based on moss analysis. Sci. Total Environ., 254: 31- 44.

Han, D., X. Liang, M. Jin, J.M. Currell, Y. Han and X. Song (2009). Hydrogeochemical indicators of groundwater flow systems in the Yangwu River alluvial fan, Xinzhou Basin, Shanxi, China; Environ. Manag., 44: 243-255.

Ieradi, L.A., M. Cristaldi, D. Mascanzoni, E. Cardarelli, R. Grossi, and L. Campanelia (1996). Genetic damage in urban mice exposed to traffic pollution. Environ. Pollut., 92: 323-328.

Jongbloed, R., T.P. Traas and R. Luttik (1996). A probablistic model for deriving soil quality criteria based on secondary poisoning top predators. II. Calculations for dichlorodiphenyltrichloroethane (DDT) and cadmium. Ecotox. Environ. Safe, 34: 279-306.

Kato, H. and E. Iwasaki (2008). In "Rashda: A Village in Dakhla Oasis". Mediterranean World, $19 \mathrm{pp}$.

Kato, H., E. Iwasaki, E. Nagasawa, H. Anyoji, N. Matsuoka and R. Kimura (2010). In "Rashda: System of Irrigation and Cultivation in a Village in Dakhla Oasis". Mediterranean World, 20 pp. 
Kato, H., S. El Beih, E. Iwasaki, A. Sefelnasr, A. Shalaby and E. Zaghloul (2014). The relationship between groundwater, Landuse, and Demoghraphy in Dakhla Oasis, Egypt. J. Asian Network for GISbased Historical Studies, 2: 3-10.

Klaassen, C.D. (2001). In "The Basic Science of Poisons". Casarett and Doull's Toxicology. New York: McGraw-Hill Medical Publishing Division.

Kooistra, L., R.S. Leuven, R. Wehrens, L.M. Buydens and P.H. Nienhuis (2001). Procedure for incorporating spatial variability in ecologic risk assessment of Dutch river floodplains. Environ. Manage., 28: 359373.

Kooistra, L., M.A. Huijbregts, A.M. Ragas, R. Wehrens and R.S. Leuven (2005). Spatial variability and uncertainty in ecologic risk assessment: A case study on the potential risk of cadmium for the little owl in a Dutch river flood plain. Environ. Sci. Technol., 39: 2177-2187.

Langner, A.N., A. Manu and M.A. Tabatabai (2011). Heavy metals distribution in an Iowa suburban landscape. J. Environ. Qual., 40: 8389.

Mahmoodabady, H., A. Mirhosiny, F. Hazery and F. Morady (2010). Investigation the effect of industrial development on groundwater pollution in arid zone (case study: Yazd province); The 1st IWA Malaysia Young Water Professionals Conference (IWAYP2010), 1-4 March 2010, Kuala Lumpur, ISBN 983-9805-86-4.

Markert, B., S. Wuenschmann, S. Fraenzle, G.A. Figueiredo, A.P. Ribeiro and M. Wang (2011). Bioindication of atmospheric trace metals with special references to megacities. Environ. Pollut., 159: 19911995.

Markov, G. (2012). Residual heavy metal concentrations in the fat dormouse (Glis glis) in an agricultural region of Bulgaria. PECKIANA, 8: 229233.

Mohamed, R.S., K.A. Allam, A.B. Farag, S.T. El Hamamy and N.S. Mahmoud (2011). Assessment of environmental impact of some industries in Helwan. J. Nuclear Radiation Physics, 6 (1): 13-29.

Ogundiran, M.B., D.T. Ogundele, P.G. Afolayan and O. Osibanjo (2012). Heavy metals levels in forage grasses, leachate and lactating cows reared around lead slag dumpsites in Nigeria. Int. J. Environ. Res., 6 (3): 695-702.

Okati, N. and M. Rezaee (2013). Heavy metals concentrations in different tissues of Persian Jird (Meriones persicus) in Sistan region. Intl. Res. J. Appl. Basic. Sci., 5 (10): 1272-1276.

Osborn, J. and I. Helmy (1980). The contemporary land mammals of Egypt (including Sinai). Field. Zool. New Seires, 5.

Egyptian J. Desert Res., 65, No. 1, 61-73 (2015) 
Pereira, R., M.L. Pereira, R. Ribeiro and F. Goncalves (2006). Tissues and hair residues and histopathology in wild rats (Rattus rattus L.) and Algerian mice (Mus spretus Lataste) from an abandoned mine area (Southeast Portugal). Environ. Pollut., 139: 561-575.

Regula, C. (2012). Acomys cahirinus: Cairo spiny mouse. Animal Diversity Web. University of Michigan.

Sanchez-Chardi, A. and J. Nadal (2007). Bioaccumulation of metals and effects of landfill pollution in small mammals. Part I. The greater white-toothed shrew, Crocidura russula. Chemosphere, 68: 703 -711.

Sanchez-Chardi, A., C. Penarroja-Matutano, C.A. Ribeiro and J. Nadal (2007). Bioaccumulation of metals and effects of a landfill in small mammals. Part II. The wood mouse, Apodemus sylvaticus. Chemosphere, 70: 101-109.

Sawicka-Kapusta, K., M. Zakrzewska, A. Kowalska, B. Lenda and M. Skrobacz (1995). Heavy metal concentrations in small mammals from Borecka forest. Arch. Ochr. Srod., (3-4): 229-234.

SCAN (Scientific Committee on Animal Nutrition) (2003). Opinion of the undesirable substances in feed, adopted on 20 February, updated on 25 April $2003 \quad$ (http://europa.eu.int/comm/food/fs/sc/scan/ out126_bis_en.pdf).

Scheuhammer, A.M. (1991). Effects of acidification on the availability of toxic metals and calcium to wild birds and mammals. Environ. Pollut., 71: 329-375.

Schleich, C.E., M.O. Beltrame and C.D. Antenucci (2010). Heavy metals accumulation in the subterranean rodent Ctenomys talarum (Rodentia: Ctenomyidae) from areas with different risk of contamination. Folia. Zool., 59 (2): 108-114.

Sedki, A., N. Lekouch, S. Gamon and A. Pineau (2003). Toxic and essential trace metals in muscle, liver and kidney of bovines from a polluted area of Morocco. The Science of the Total Environment, 317: 201205.

Serbaji, M.M., C. Azri and K. Medhioub (2012). Anthropogenic contributions to heavy metal distributions in the surface and subsurface sediments of the Northern Coast of Sfax, Tunisia. Int. J. Environ. Res., 6 (3): 613-626.

Shore, R.F. and B.A. Rattner (2001). In "Ecotoxicology of Wild Mammals". Wiley, Chichester, New York, Weinheim.

Shore, R.F. and P.E. Douben (1994). The ecotoxicological significance of cadmium intake and residues in terrestrial small mammals. Ecotox. Environ. Safe, 29: 101-112.

Soltan, M.E. (1999). Evaluation of groundwater quality in Dakhla Oasis (Egyptian Western Desert). Environmental Monitoring and Assessment, 57: 157-168.

Egyptian J. Desert Res., 65, No. 1, 61-73 (2015) 
Soltan, M.E. and R.M. Issa (1996). The suitability of ground water in Aswan Governorate for different daily uses. AMSE, 54 (1 and 2): 55.

Sumbera, R., V. Barus and F. Tenora (2003). Heavy metals in the silvery mole-rat, Heliophobius argenteocinereus (Bathyergidae: Rodentia) from Malawi. Folia. Zool., 52: 149-153.

Swarup, D. and R.C. Patra (2005). Environmental pollution and its impact on domestic animals and wildlife. Ind. J. Animal. Sci., 75: 231-240

Swiergosz-Kowalewska, R., M. Gramatyka and W. Reczynski (2005). Metals distribution and interactions in tissues of shrews (Sorex spp.) from copper- and zinc-contaminated areas in Poland. J. Environ. Qual., 34: 1519-1529.

Topolska, K., K. Sawicka-Kapusta and E. Cieslik (2004). The effect of contamination of the Krakow region on heavy metals content in the organs of bank voles (Clethrionomys glareolus, Schreber, 1780). Polish. J. Environ. Stud., 13: 103-109.

Torres, K.C. and M.L. Johnson (2001). Bioaccumulation of metals in plants, arthropods, and mice at a seasonal wetland. Environmental Toxicology and Chemistry, 20: 2617-2626. 
تركيز العناصر الثقلية كأدلة حيوية على التلوث في أنسجة الفار الثوكي تحت

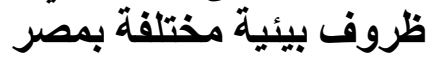

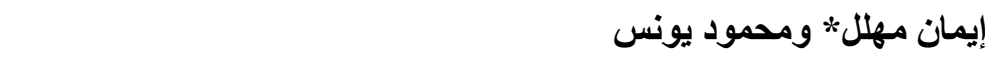

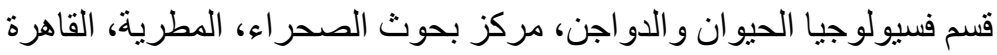

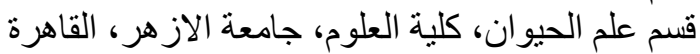

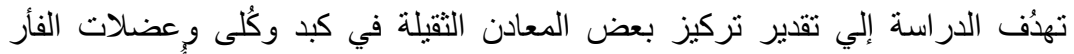
الشوكي أكوميس كاهريناس من منطقتين، إحداهما طبيعية (الواحات الداخلة) و الأخرى صنيز صناعية

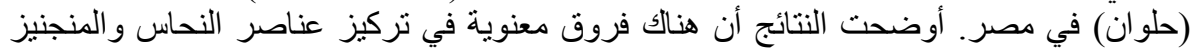

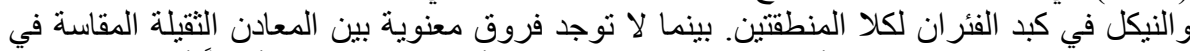

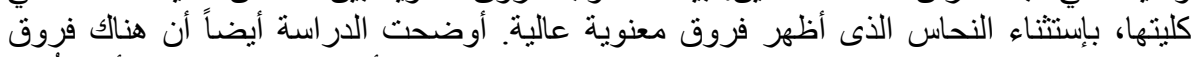

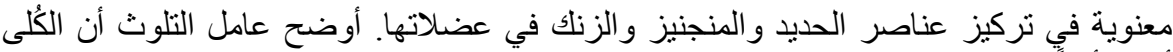

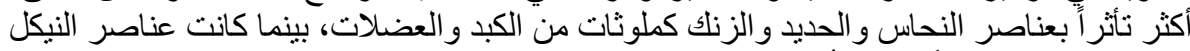

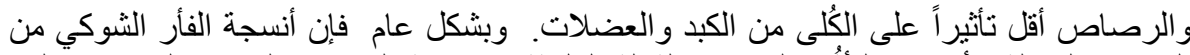

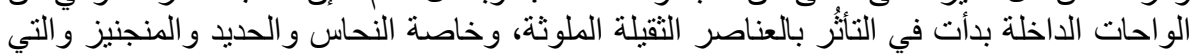

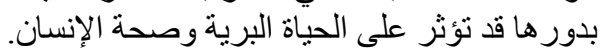

